\title{
Efficient approach to thiazolidinones via a one-pot three-component reaction involving 2-amino-1-phenylethanone hydrochloride, aldehyde and mercaptoacetic acid
}

\author{
Asha Vasantrao Chate ${ }^{a}$, Akash Gitaram Tathe ${ }^{a}$, Prajyot Jayadev Nagtilak ${ }^{a}$, Sunil M. Sangle ${ }^{\text {, }}$ \\ Charansingh H. Gill a,* \\ a Department of Chemistry, Dr. Babasaheb Ambedkar Marathwada University, Aurangabad-431004, M.S., India \\ ${ }^{\mathrm{b}}$ Rajaram College, Kolhapur-416004, M.S., India
}

\section{A R T I C L E I N F O}

\section{Article history:}

Received 15 June 2016

Accepted 21 August 2016

Published 5 November 2016

\section{Keywords:}

Tandem reaction

Thiazolidinones

Heterocycles

$\mathrm{N}, \mathrm{N}$-diisopropylethylamine

Cyclization

\begin{abstract}
A B S T R A C T
A highly efficient three-component reaction has been developed for the synthesis of thiazolidinones involving the reaction of 2-amino-1-phenylethanone hydrochloride with an aromatic aldehyde and mercaptoacetic acid in the presence of diisopropylethylamine in a single pot. Critically, this reaction exhibited excellent chemoselectivity, with the nitrogen atom of the 2-amino-1-phenylethanone component reacting selectively with the aromatic aldehyde to give the corresponding Schiff base. Nucleophilic attack at the carbon of the Schiff base by the sulfur atom of mercaptoacetic, followed by a cyclocondensation reaction between the nitrogen and the carboxylic acid moiety afforded the desired thiazolidinones, which were fully characterized by spectroscopic techniques.
\end{abstract}

(C) 2016, Dalian Institute of Chemical Physics, Chinese Academy of Sciences. Published by Elsevier B.V. All rights reserved.

\section{Introduction}

For more than a century, heterocyclic compounds have ranked amongst the most important classes of organic compounds. Notably, compounds belonging to this class participate in a wide range of important biochemical processes, as well as being key components of our genetic code (e.g., DNA and RNA). It has been reported that around half of the therapeutic agents developed and commercialized to date consist of heterocyclic compounds [1]. Biologically active molecules containing heteroatoms such as nitrogen, sulfur and oxygen, have always attracted considerable interest from chemist because of the challenges associated with their syntheses and the potential application of these compounds as therapeutic agents and tool compounds in medicine and the pharmaceutical sciences. The development of new and efficient procedures for the generation of heterocyclic compounds is therefore highly desired. Diversity-oriented synthesis has been successfully applied to the synthesis of structurally diverse and complex collections of biologically active pharmacophores. Among the many strategies utilized to date, the sequential linking of several different components in one reaction vessel has been studied extensively as an efficient method for the rapid construction of increasingly complex molecular architectures. Critically, this process avoids the requirement for costly and environmentally unfriendly isolation and purification of intermediates [2-5]. Multi-component reactions (MCRs) of this type represent efficient approaches for the synthesis of five-membered heterocycles containing sulfur, nitrogen and oxygen in one moiety, allowing for the production of privileged scaffolds of considerable me-

* Corresponding author. Tel: +91-240-2403311; Fax: +91-240-2400491; E-mail: chgill16@gmail.com DOI: 10.1016/S1872-2067(16)62536-6 | http://www.sciencedirect.com/science/journal/18722067 | Chin. J. Catal., Vol. 37, No. 11, November 2016 
dicinal value.

Five-membered rings containing three heteroatoms are a privileged class of heterocyclic structures with proven utility in medicinal chemistry. For example, 4-thiazolidinones are important synthetic intermediates, which can also be found in a wide range of therapeutic agents with interesting pharmacological activities. The 4-thiazolidinone ring system is a versatile structure that can be found in numerous drugs currently being used in clinical practice to treat various diseases. Compounds belonging to this structural class have also been reported to exhibit a broad range of interesting biological properties, including hypoglycemic, antibacterial [6], anticancer [7-10], antitubercular [11-13], antioxidant [14], anti-inflammatory [15], COX-1 inhibitory [16], anti-HIV [17-20] and antihistaminic [21] activities. The chemical structures of several important thiazolidinone-containing compounds from the literature are shown in Fig. 1.

Several methods have been reported in the literature for the synthesis of 4-thiazolidinones. The main synthetic routes to 1,3-thiazolidin-4-ones involve the three-component reaction of an amine with a carbonyl group-containing compound and a mercaptocarboxylic acid. This classical approach can either be conducted as a one-pot three-component condensation or a two-step process. Mechanistically, these reactions begin with the formation of an imine, followed by the nucleophilic attack of the nitrogen atom of the amine component on the carbonyl carbon of the aldehyde or ketone. The resulting imine then undergoes a nucleophilic attack from the sulfur nucleophile, followed by an intramolecular cyclocondensation reaction to give the desired product [22-24]. Numerous catalysts [25-31] have been reported to accelerate the cyclocondensation step of this reaction. Several solid phase [32], microwave [33] and polymer supported [4,34-37] systems have also been developed. MCRs [38] are well-known procedures for the rapid construction of diverse chemical structures. Notably, MCRs allow for the synthesis of complex molecules in a modular manner, thereby allowing for the incorporation of one or more units in a final product in a well-defined and predictable order.

With the three-component, one-flask preparation of TZD already reported, we report here a synthetic approach to these heterocycles involving three-component, one-flask, sequential $1+2+3$ atom construction of five-membered ring novel 3-(2-oxo-2-phenylethyl)-2-phenylthiazolidin-4-one. With this in mind, the aim of the current paper was to achieve the synthesis of a new series of thiazolidinones by the condensation of novel amines, with aromatic aldehydes and thioglycolic acid via a one-pot, three-component reaction using DIPEA as a base according to a MCR protocol.

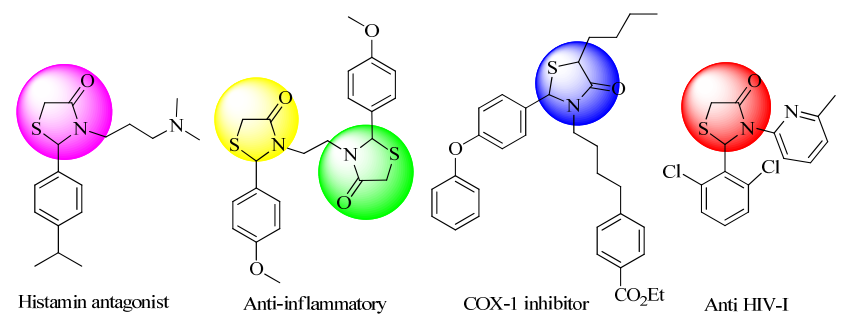

Fig. 1. Some biologically important thiazolidinone compounds.

\section{Experimental}

\subsection{Materials and methods}

All of the chemicals used in this study were purchased from commercial suppliers and used as supplied without further purification. Melting points (M.P.) were determined in open capillary tubes and reported as the uncorrected values. ${ }^{1} \mathrm{H}$ NMR spectra were recorded on a $400-\mathrm{MHz}$ Varian spectrometer model Avance-II (Bruker) using DMSO- $d_{6}$ as a solvent. Chemical shifts $(\delta)$ were reported in ppm relative to TMS, which was used as an internal reference standard, and the coupling constants () were expressed in hertz $(\mathrm{Hz})$. Mass spectra were recorded on a Macro mass spectrometer (Waters) using electrospray ionization. The reactions were monitored by thin layer chromatography (TLC) using silica-coated plates (Merck).

\subsection{General procedure for the synthesis of 3-(2-oxo-2-phenylethyl)-2-phenylthiazolidin-4-ones $\mathbf{4 a - 4 m}$}

To a solution of 2-amino-1-phenylethanone hydrochloride 2a (1 mmol) in toluene $(8 \mathrm{~mL})$ was added benzaldehyde $1 \mathbf{a}(1$ $\mathrm{mmol}$ ) and the mixture was heated for $1 \mathrm{~h}$ in the presence of DIPEA ( $3 \mathrm{mmol}$ ) to afford the corresponding Schiff base. The reaction was then treated with mercaptoacetic acid 3 (3 mol), and the resulting mixture was heated for $3-4 \mathrm{~h}$ to give the corresponding substituted thiazolidinone $\mathbf{4 a - 4 m}$. Upon completion of the reaction, as determined by TLC analysis, the toluene was removed under vacuum to give a viscous oil, which was treated with a saturated aqueous $\mathrm{NaHCO}_{3}$ solution to remove any unreacted mercaptoacetic acid. The product subsequently crystallized and was washed with water before being dried under vacuum at $40{ }^{\circ} \mathrm{C}$ and recrystallized from alcohol to give the pure product.

\subsection{Spectral data for representative compounds}

3-(2-0xo-2-phenylethyl)-2-phenylthiazolidin-4-one (4a). ${ }^{1} \mathrm{H}$ NMR (DMSO, $400 \mathrm{MHz}$ ): $\delta 3.66-3.93$ (dd, overlapped, $2 \mathrm{H}$, methylene), $4.26\left(\mathrm{~s}, 2 \mathrm{H}, \mathrm{CH}_{2}\right), 5.80(\mathrm{t}, 1 \mathrm{H}$, methine), 7.02-7.14 (m, 4H, Ar-H), 7.27-7.57 (m, 5H, Ar-H); ${ }^{13} \mathrm{C}$ NMR (100 MHz, $\left.\mathrm{CDCl}_{3}\right): \delta 193.1,170.3,140.1,138.5,128.8,127.3,126.3,62.1$, 49.8, 32.4. LC-MS (ES+) m/z: $298.12[\mathrm{M}]^{+} \& 296.3[\mathrm{M}-\mathrm{H}]^{+}$. Elemental analysis Calcd. for $\mathrm{C}_{17} \mathrm{H}_{15} \mathrm{NO}_{2} \mathrm{~S}$ : C, 68.66; $\mathrm{H}, 5.08$; $\mathrm{N}, 4.71$; S, 10.78; Found: C, 68.86; H, 5.18; N, 4.61.

2-(4-Chlorophenyl)-3-(2-oxo-2-phenylethyl)thiazolidin-4one (4b). ${ }^{1} \mathrm{H}$ NMR (DMSO, $400 \mathrm{MHz}$ ): $\delta$ 3.75-4.06 (dd, overlapped, $2 \mathrm{H}$, methylene), $4.78\left(\mathrm{~s}, 2 \mathrm{H}, \mathrm{CH}_{2}\right), 5.87(\mathrm{t}, 1 \mathrm{H}$, methine), 7.18-7.28 (m, 4H, Ar-H), 7.47-7.86 (m, 5H, Ar-H); ${ }^{13} \mathrm{C}$ NMR $\left(100 \mathrm{MHz}, \mathrm{CDCl}_{3}\right): \delta 193.6,171.0,144.7,135.9,132.8,127.9$, 63.5, 48.8, 33.5. LC-MS (ES+) $m / z: 332.04[\mathrm{M}+\mathrm{H}]+$ \& 334.12 $[\mathrm{M}+2 \mathrm{H}]^{+}$. Elemental analysis Calcd. for $\mathrm{C}_{17} \mathrm{H}_{14} \mathrm{ClNO}_{2} \mathrm{~S}: \mathrm{C}, 61.53$; H, 4.25; N, 4.22; S, 9.66; Found: C, 61.59; H, 4.30; N, 4.12.

2-(4-Hydroxyphenyl)-3-(2-oxo-2-phenylethyl)thiazolidin-4one (4c). ${ }^{1} \mathrm{H}$ NMR (DMSO, $400 \mathrm{MHz}$ ): $\delta 3.32-3.72$ (dd, overlapped, $2 \mathrm{H}$, methylene), $4.81\left(\mathrm{~s}, 2 \mathrm{H}, \mathrm{CH}_{2}\right), 5.75(\mathrm{t}, 1 \mathrm{H}$, methine), 6.86-6.95 (m, 4H, Ar-H), 7.12-7.71 (m, 5H, Ar-H), 10.06 (s, 1H, 
OH); ${ }^{13} \mathrm{C}$ NMR (100 MHz, $\left.\mathrm{CDCl}_{3}\right): \delta 192.6,170.7,155.4,136.8$, 130.6, 123.7, 115.2, 61.9, 47.1, 32.8. LC-MS (ES+) $\mathrm{m} / \mathrm{z}: 313.08$ $[\mathrm{M}]^{+}$. Elemental analysis Calcd. for $\mathrm{C}_{17} \mathrm{H}_{15} \mathrm{NO}_{3} \mathrm{~S}$ : C, 65.16; $\mathrm{H}$, 4.82; N, 4.47; S, 10.23; Found: C, 65.22; H, 4.89; N, 4.40.

2-(3-Methoxyphenyl)-3-(2-oxo-2-phenylethyl)thiazolidin-4one (4d). ${ }^{1} \mathrm{H}$ NMR (DMSO, $400 \mathrm{MHz}$ ): $\delta$ 3.65-3.69 (dd, overlapped, $2 \mathrm{H}$, methylene), $3.79\left(\mathrm{~s}, 3 \mathrm{H}, \mathrm{OCH}_{3}\right), 5.11\left(\mathrm{~s}, 2 \mathrm{H}, \mathrm{CH}_{2}\right)$, $5.96(\mathrm{t}, 1 \mathrm{H}$, methine), 6.85-7.09 (m, 3H, Ar-H), $7.17(\mathrm{~s}, 1 \mathrm{H}$, $\mathrm{Ar}-\mathrm{H}), 7.20-7.64$ (m, 5H, Ar-H); ${ }^{13} \mathrm{C}$ NMR (100 MHz, $\left.\mathrm{CDCl}_{3}\right): \delta$ 193.6, 172.4, 159.0, 140.4, 134.8, 129.9, 127.3, 122.7, 120.8, 111.1, 63.4, 55.6, 48.4, 32.5. LC-MS (ES+) m/z: 327.09 [M+H]+. Elemental analysis Calcd. for $\mathrm{C}_{18} \mathrm{H}_{17} \mathrm{NO}_{3} \mathrm{~S}$ : C, 66.03; H, 5.23; N, 4.28; S, 9.79; Found: C, 66.13; H, 5.300; N, 4.20.

3-(2-0xo-2-phenylethyl)-2-( $p$-tolyl)thiazolidin-4-one (4e). ${ }^{1} \mathrm{H}$ NMR (DMSO, $400 \mathrm{MHz}$ ): $\delta 2.32\left(\mathrm{~s}, 3 \mathrm{H}, \mathrm{CH}_{3}\right), 3.33-3.73$ (dd, overlapped, $2 \mathrm{H}$, methylene), $4.85\left(\mathrm{~s}, 2 \mathrm{H}, \mathrm{CH}_{2}\right), 5.75(\mathrm{t}, 1 \mathrm{H}$, methine), 7.02-7.27 (m, 4H, Ar-H), 7.20-7.77 (m, 5H, Ar-H); ${ }^{13} \mathrm{C}$ NMR $\left(100 \mathrm{MHz}, \mathrm{CDCl}_{3}\right): \delta 193.4,170.9,139.0,135.8,133.9$, 127.9, 63.4, 48.4, 31.8, 22.7. LC-MS (ES+) $m / z: 312.10[\mathrm{M}+\mathrm{H}]^{+}$. Elemental analysis Calcd. for $\mathrm{C}_{18} \mathrm{H}_{17} \mathrm{NO}_{2} \mathrm{~S}$ : C, 69.43; H, 5.50; N, 4.50; S, 10.30; Found: C, 69.49; H, 5.58; N, 4.42.

3-(2-0xo-2-( $p$-tolyl)ethyl)-2-phenylthiazolidin-4-one (4f). ${ }^{1} \mathrm{H}$ NMR (DMSO, $400 \mathrm{MHz}$ ): $\delta 2.49$ (s, 3H, $\mathrm{CH}_{3}$ ), 3.64-3.98 (dd, overlapped, $2 \mathrm{H}$, methylene), $4.27\left(\mathrm{~s}, 2 \mathrm{H}, \mathrm{CH}_{2}\right), 5.82(\mathrm{t}, 1 \mathrm{H}$, methine), 7.10-7.19 (m, 4H, Ar-H), 7.37-7.59 (m, 4H, Ar-H); ${ }^{13} \mathrm{C}$ NMR (100 MHz, $\left.\mathrm{CDCl}_{3}\right): \delta 193.2,171.4,145.0,142.2,139.2$, 133.1, 128.5, 127.0, 124.6, 63.5, 49.5, 32.8, 21.0. LC-MS (ES+) $\mathrm{m} / \mathrm{z}: 312.12\left([\mathrm{M}]^{+} \& 310.31[\mathrm{M}-\mathrm{H}]^{+}\right.$. Elemental analysis Calcd. for $\mathrm{C}_{18} \mathrm{H}_{17} \mathrm{NO}_{2} \mathrm{~S}$ : C, 69.43; H, 5.50; N, 4.50; S, 10.30; Found: C, 69.53; H, 5.40; N, 4.30; S, 10.21 .

2-(4-Chlorophenyl)-3-(2-oxo-2-( $p$-tolyl)ethyl)thiazolidin-4one (4h): ${ }^{1} \mathrm{H}$ NMR (DMSO, $\left.400 \mathrm{MHz}\right): \delta 2.50\left(\mathrm{~s}, 3 \mathrm{H}, \mathrm{CH}_{3}\right.$ ), 3.75-3.98 (dd, overlapped, $2 \mathrm{H}$, methylene), 4.85 (s, $2 \mathrm{H}, \mathrm{CH}_{2}$ ), 5.79 (t, 1H, methine), 7.17-7.29 (m, 4H, Ar-H), 7.35-7.73 (m, $4 \mathrm{H}, \mathrm{Ar}-\mathrm{H}) ;{ }^{13} \mathrm{C}$ NMR $\left(100 \mathrm{MHz}, \mathrm{CDCl}_{3}\right): \delta 193.3,170.7,142.7$, 141.2, 131.9, 128.8, 126.9, 62.7, 49.4, 33.8, 21.8. LC-MS (ES+) $\mathrm{m} / \mathrm{z}: 345.06[\mathrm{M}]^{+} \& 347.31\left([\mathrm{M}+2 \mathrm{H}]^{+}\right.$. Elemental analysis Calcd. for $\mathrm{C}_{18} \mathrm{H}_{16} \mathrm{ClNO}_{2} \mathrm{~S}$ : C, 62.51; H, 4.66; N, 4.05; S, 9.27; Found: C, 62.59; H, 4.72; N, 4.00 .

2-(3-Methoxyphenyl)-3-(2-oxo-2-( $p$-tolyl)ethyl)thiazolidin4-one (4i). ${ }^{1} \mathrm{H}$ NMR (DMSO, $400 \mathrm{MHz}$ ): $\delta 2.49$ (s, 3H, $\mathrm{CH}_{3}$ ), 3.72-3.78 (dd, overlapped, $2 \mathrm{H}$, methylene), 3.92 (s, $3 \mathrm{H}, \mathrm{OCH}_{3}$ ), $4.82\left(\mathrm{~s}, 2 \mathrm{H}, \mathrm{CH}_{2}\right), 5.55(\mathrm{t}, 1 \mathrm{H}$, methine), 6.59-6.89 (m, 3H, $\mathrm{Ar}-\mathrm{H}), 7.30$ (s, 1H, Ar-H), 7.32-7.39 (m, 4H, Ar-H); ${ }^{13} \mathrm{C}$ NMR (100 MHz, CDCl $): \delta 193.7,170.7,158.7,141.3,139.9,131.9$, 129.8, 127.9, 63.7, 55.4, 49.6, 33.1, 21.8. LC-MS (ES+) $\mathrm{m} / \mathrm{z}$ : $342.11[\mathrm{M}]^{+}$. Elemental analysis Calcd. for $\mathrm{C}_{19} \mathrm{H}_{19} \mathrm{NO}_{3} \mathrm{~S}$ : C, 66.84; H, 5.61; N, 4.10; S, 9.39; Found: C, 66.90; H, 5.70; N, 4.02.

3-(2-0xo-2-phenylethyl)-2-(thiophen-2-yl)thiazolidin-4-one (4j). ${ }^{1} \mathrm{H}$ NMR (DMSO, $400 \mathrm{MHz}$ ): $\delta 2.56$ (s, 3H, CH ), 3.79-3.96 (dd, overlapped, $2 \mathrm{H}$, methylene), $4.84\left(\mathrm{~s}, 2 \mathrm{H}, \mathrm{CH}_{2}\right), 6.16(\mathrm{t}, 1 \mathrm{H}$, methine), 6.94-6.96 (dd, 2H, Ar-H), 7.29-8.50 (m, 6H, Ar-H); ${ }^{13} \mathrm{C}$ NMR $\left(100 \mathrm{MHz}, \mathrm{CDCl}_{3}\right): \delta 193.4,170.6,139.5,134.6,133.7$, 127.8, 126.6, 58.9, 49.5, 32.7. LC-MS (ES+) m/z: $304.14[\mathrm{M}+\mathrm{H}]^{+}$. Elemental analysis Calcd. for $\mathrm{C}_{15} \mathrm{H}_{13} \mathrm{NO}_{2} \mathrm{~S}_{2}$ : C, 59.38; $\mathrm{H}, 4.32 ; \mathrm{N}$, 4.62; S, 21.14; Found: C, 59.48; H, 4.40; N, 4.52.

3-(2-0xo-2-( $p$-tolyl)ethyl)-2-(thiophen-2-yl)thiazolidin-4- one (4l). ${ }^{1} \mathrm{H}$ NMR (DMSO, $\left.400 \mathrm{MHz}\right): \delta 2.50\left(\mathrm{~s}, 3 \mathrm{H}, \mathrm{CH}_{3}\right.$ ), 3.76-3.92 (dd, overlapped, $2 \mathrm{H}$, methylene), 4.92 (s, 2H, $\mathrm{CH}_{2}$ ), 5.75 (t, 1H, methine), 7.22-7.30 (dd, 2H, Ar-H), 7.74-8.10 (m, $5 \mathrm{H}, \mathrm{Ar}-\mathrm{H}) ;{ }^{13} \mathrm{C}$ NMR $\left(100 \mathrm{MHz}, \mathrm{CDCl}_{3}\right): \delta 193.6,170.9,141.6$, 137.8, 131.8, 127.6, 126.4, 59.9, 48.1, 32.1. LC-MS (ES+) $m / z$ : $318.15[\mathrm{M}+\mathrm{H}]^{+}$. Elemental analysis Calcd. for $\mathrm{C}_{16} \mathrm{H}_{15} \mathrm{NO}_{2} \mathrm{~S}_{2}: \mathrm{C}$, 60.54; H, 4.76; N, 4.41; S, 20.20; Found: C, 60.60; H, 4.86; N, 4.31 .

\section{Results and discussion}

Herein, we report a new convergent approach for the efficient and convenient synthesis of a novel series of thiazolidinone derivatives, which could be conveniently incorporated into a wide range of different drug molecules. This type of convergent approach has several advantages over existing procedures, including using catalyst for accelerating cyclocondensation $N, N^{\prime}$-dicyclohexylcarbodiimide (DCC), $O$-(benzotriazol-yl)$N, N, N, N^{\prime \prime}$-tetramethyluronium hexafluoro phosphate (HBTU), activated fly ash and the use of microwave heating. Although several 2-amino-1-phenylethanone hydrochlorides are known in the literature, the reported syntheses of these compounds generally require $2-3 \mathrm{~h}$ at room temperature and are formally recognized as two-step procedures [39,40]. To the best of our knowledge, the 3-(2-oxo-2-phenylethyl)-2-phenylthiazolidin-4ones $(\mathbf{4 a - 4 m})$ reported in this study have not been reported elsewhere in the literature to date.

Compounds $\mathbf{4 a}-\mathbf{4 m}$ were prepared from two slightly different 2-amino-1-phenylethanone hydrochloride salts, which were themselves prepared from the corresponding phenacyl chlorides according to a two-step procedure. Thus, the Delépine reaction [39] of the phenacyl chlorides with hexamethylenetetramine afforded the corresponding heximinium salts in high yields (90\%-92\%), which were subsequently hydrolyzed under acidic conditions to give the corresponding amines as the hydrochloride salts (Scheme 1) [40]. These amine hydrochloride salts were then treated with a series of benzaldehydes (1a-1m) in the presence of $\mathrm{N}, \mathrm{N}$-diisopropylethylamine (DIPEA) to give the corresponding imines, which underwent a cyclocondensation reaction with mercaptoacetic acid in toluene at $110^{\circ} \mathrm{C}$ to give the desired thiazolidinones $\mathbf{4 a - 4 m}$ (Scheme 2). Compound 4 a was obtained in $48 \%$ yield when $\mathrm{CH}_{3} \mathrm{CN}$ was

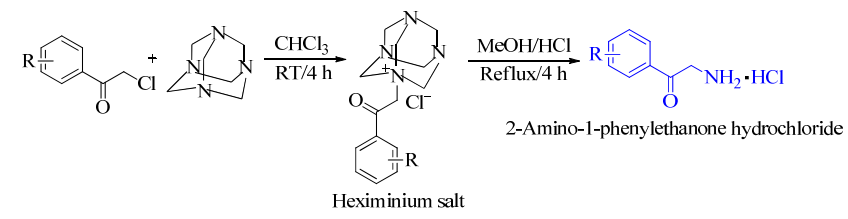

Scheme 1. Synthesis of the substituted 2-amino-1-phenylethanone hydrochlorides $\mathbf{2 a}$.

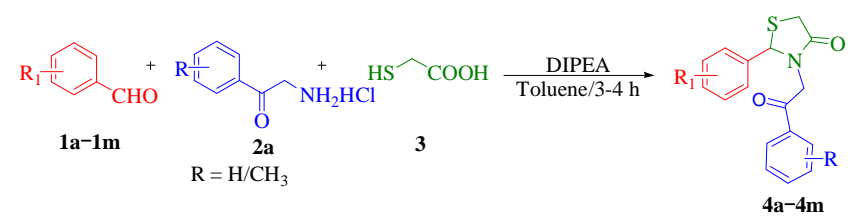

Scheme 2. Synthesis of substituted 3-(2-oxo-2-phenylethyl)-2-phenylthiazolidin-4-one derivatives. 
used as the solvent at $110{ }^{\circ} \mathrm{C}$ for $7 \mathrm{~h}$ (Table 1 , entry 1 ). The yield was improved when the reaction was performed at 110 ${ }^{\circ} \mathrm{C}$ for $8 \mathrm{~h}$, and a moderate yield was obtained using triethylamine as a base. When the reaction time was extended to $10 \mathrm{~h}$, the yield increased to $68 \%$. Pleasingly, the addition of DIPEA to the reaction led to an increase in the yield of the desired product 4 a to $75 \%$ after $3 \mathrm{~h}$.

The crude products were purified by column chromatography over silica gel eluting with a 3:1 $(\mathrm{v} / \mathrm{v})$ mixture of petroleum ether/ethyl acetate to give the pure compounds. We have investigated these reactions in more detail. Solvent screening indicated that toluene was still the best solvent for this reaction, and when the reaction time was extended to $4 \mathrm{~h}$, the desired product was obtained in $85 \%$ yield (Table 2 , entry 1 ). However, lowering the DIPEA led to a decrease in yield, whereas increasing the amount of DIPEA had the opposite effect. We also found that when the reaction was carried out un-
Table 1

Optimization of solvent study for the synthesis on thiazolidinone derivatives.

\begin{tabular}{lcc}
\hline Entry & Solvent & Yield * $(\%)$ \\
\hline 1 & $\mathrm{CH}_{3} \mathrm{CN}$ & 48 \\
2 & PEG-400 & 52 \\
3 & THF & 46 \\
4 & Toluene & 85 \\
5 & Dichloromethane & 35 \\
\hline
\end{tabular}

der a controlled temperature, the result was improved. We explored a variety of different solvents and reaction parameters until we obtained the desired thiazolidinones in suitably high yields (Scheme 2, Table 1). Thiazolidinone 4a was prepared in $66 \%$ yield (56\% considering both reactions) using a stepwise sequence, and in $85 \%$ yield under tandem conditions (Table 2, entries 1-12). We found that a tandem sequence was

Table 2

Synthesis of substituted novel 3-(2-oxo-2-phenylethyl)-2-phenylthiazolidin-4-one 4a-4m derivatives.

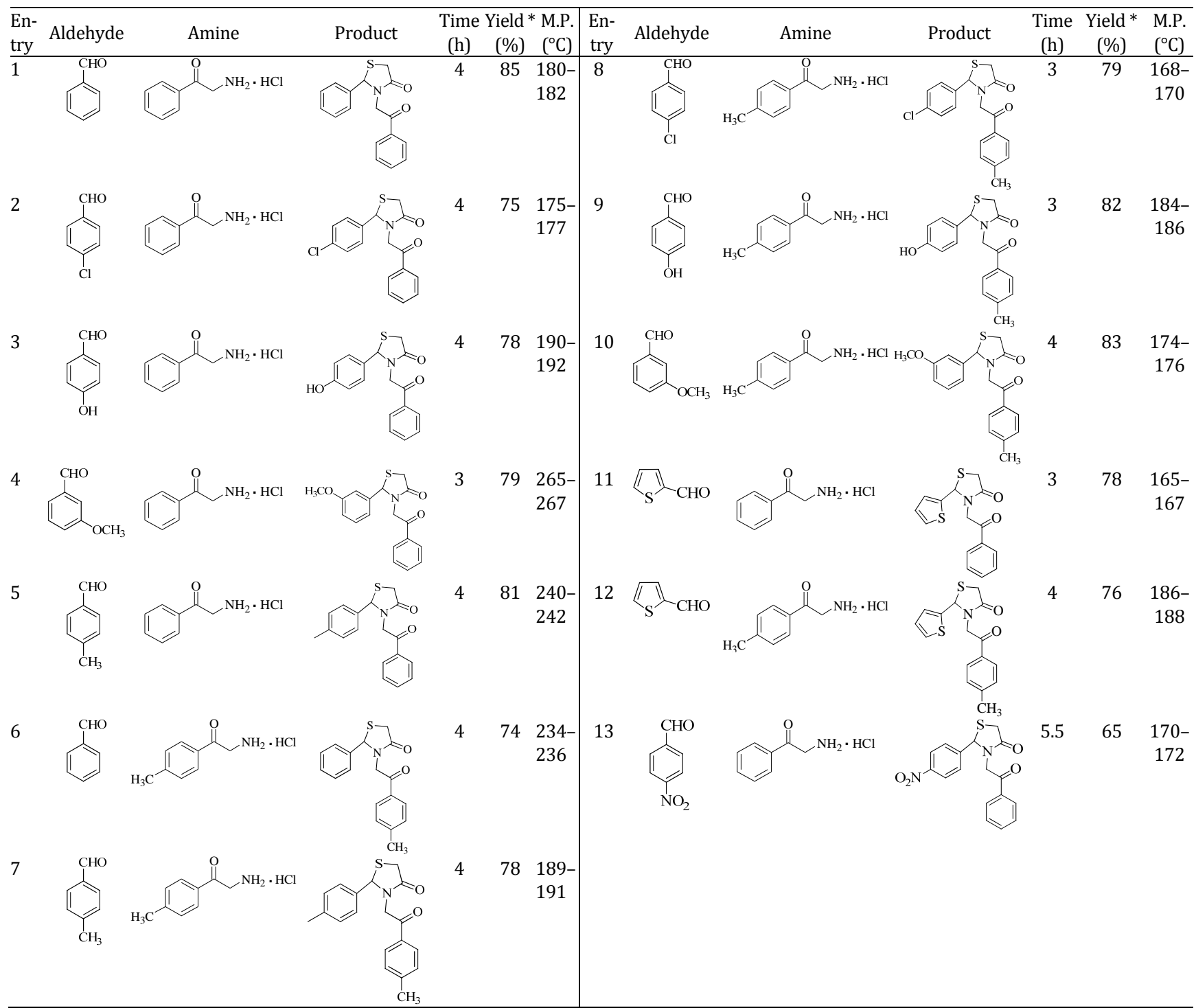

* Isolated yields obtained using 2-amino-1-phenylethanone hydrochloride (1.0 mmol), aldehyde (1.0 mmol), mercaptoacetic acid (3.0 mmol) and DIPEA $(3.0 \mathrm{mmol})$ in toluene at $110^{\circ} \mathrm{C}$. 


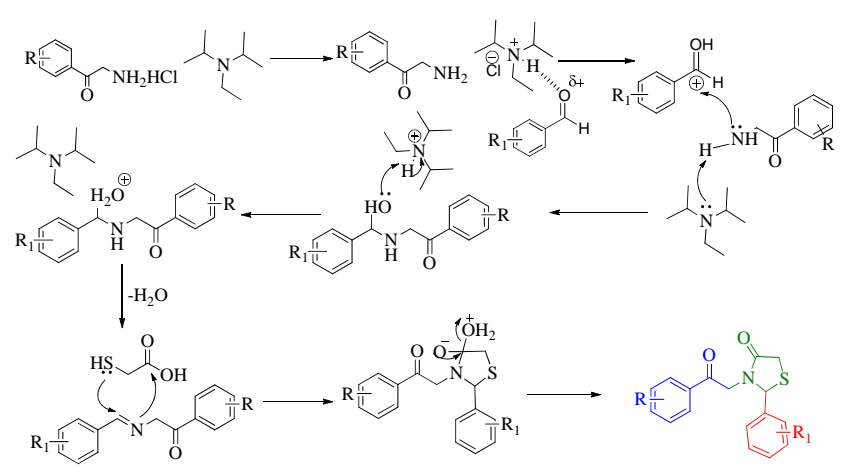

Scheme 3. Plausible mechanism for the synthesis of 3-(2-oxo-2-phenylethyl)-2-phenylthiazolidin-4-one derivatives.

more efficient than a stepwise conversion under thermal conditions. From a mechanistic perspective, we believe that this reaction proceeds by the initial nucleophilic attack of the sulfur atom of the mercaptoacetic acid to the carbon atom of the imine group, followed by an intramolecular cyclization, resulting in the elimination of water (Scheme 2).

Under optimized conditions (Table 1, entry 4), we converted a wide range of aromatic and heterocyclic aldehydes (1a-1m) to the corresponding thiazolidin-4-ones (Table 2). Aromatic aldehydes reacted smoothly to afford the desired products in good yields (70\%-85\%). Notably, the heterocyclic aldehyde 2-thiophene-carboxaldehyde also reacted to afford the desired thiazolidin-4-one in $78 \%$ yield. The reaction appeared to be independent of the presence of electron-withdrawing or electron-donating substituents on the aromatic ring of the aldehyde. All of the thiazolidin-4-one products were purified by crystallization and their structures were confirmed by ${ }^{1} \mathrm{H}$ NMR, ${ }^{13} \mathrm{C}$ NMR, mass spectrometry and elemental analyses.

A plausible mechanism for the formation of 3-(2-oxo-2phenylethyl)-2-phenylthiazolidin-4-one in the presence of DIPEA is shown in Scheme 3. 2-Amino-1-phenylethanone hydrochloride would initially react with DIPEA to give the corresponding free amine, which would react with the activated carbonyl group of the aldehyde (activated by the DIPEA $\cdot \mathrm{HCl}$ salt) to give the corresponding imine. Nucleophilic attack at the imine carbon by the sulfur atom of mercaptoacetic acid, followed by the cyclocondensation of the nitrogen atom of the imine into the carboxylic acid group would give the desired 3-(2-oxo-2-phenylethyl)-2-phenylthiazolidin-4-one.

\section{Conclusions}

We have developed a new method for the convergent synthesis of 3-(2-oxo-2-phenylethyl)-2-phenylthiazolidin-4-one derivatives using DIPEA as a base. These thiazolidinone derivatives were prepared via a one-pot, three-component protocol, providing rapid access to a series of biologically valuable sulfur-nitrogen heterocycles. This method is mild and versatile, showing good functional group tolerance, allowing for the successful reaction of novel amines with aromatic aldehydes and mercaptoacetic acid to give a small library of new 3-(2-oxo-2phenylethyl)-2-phenylthiazolidin-4-ones.

\section{Acknowledgments}

This work was supported by Special Assistance Programme SAP, University Grants Commission, New Delhi, India, intended to encourage the pursuit of excellence and teamwork in advanced teaching and research to accelerate the realization of international standards in specific fields, and also Sophisticated Analytical Instrumentation Facility, Chandigarh, for providing characterization facility for this work.

\section{References}

[1] M. A. Ghannoum, J. Invest. Dermatol., 2001, 6, 188-196.

[2] I. V. Magedov, L. Frolova, M. Manpadi, U. devi Bhoga, H. Tang, N. M. Evdokimov, O. George, K. H. Georgiou, S. Renner, M. Getlik, T. L. Kinnibrugh, M. A. Fernandes, S. Van Slambrouck, W. F. A. Steelant, C. B. Shuster, S. Rogelj, W. A. L. van Otterlo, A. Kornienko, J. Med. Chem., 2011, 54, 4234-4246.

[3] T. J. J. Mueller, Angew. Chem. Int. Ed., 2007, 46, 2977-2978.

[4] D. J. Ramon, M. Yus, Angew. Chem. Int. Ed., 2005, 44, 1602-1634.

[5] G. H. Posner, Chem. Rev., 1986, 86, 831-844.

[6] V. S. Palekar, A. J. Damle, S. R. Shukla, Eur. J. Med. Chem., 2009, 44, 5112-5116.

[7] Q. Zhang, H. Y. Zhou, S. M. Zhai, B. Yan, Curr. Pharm. Des., 2010, 16, 1826-1842.

[8] S. Desai, P. B. Desai, K. R. Desai, Heterocycl. Commun., 1999, 5, 385-390.

[9] H. Y. Zhou, S. H. Wu, S. M. Zhao, A. F. Liu, Y. Sun, R. S. Li, Y. Zhang, S. Ekins, P. W. Swaan, B. L. Fang, B. Zhang, B. Yan, J. Med. Chem., 2008, 51, 1242-1251.

[10] M. Sala, A. Chimento, C. Saturnino, I. M. Gomez-Monterrey, S. Musella, A. Bertamino, C. Milite, M. Stefania, A. Caruso, R. Sirianni, P. Tortorella, E. Novellino, P. Campiglia, V. Pezzi, Bioorg. Med. Chem. Lett., 2013, 23, 4990-4995.

[11] V. P. Trivedi, N. K. Undavia, P. B. Trivadi, J. Indian Chem. Soc., 2004, 81, 506-508.

[12] G. Kucukguzel, A. Kaocatepe, E. De Clercq, F. Sahinv, M. Gulluce, Eur. J. Med. Chem., 2006, 41, 353-359.

[13] T. Srivastava, A. K. Gaikwad, W. Haq, S. Sinha, S. B. Katti, Arkivoc, 2005, (ii), 120-130.

[14] M. H. Shih, F. Y. Ke, Bioorg. Med. Chem., 2004, 12, 4633-4643.

[15] M. G. Vigorita, R. Ottana, F. Monforte, R. Maccari, A. Trovato, M. T. Monforte, M. F. Taviano, Bioorg. Med. Chem. Lett., 2001, 11, 2791-2794.

[16] G. C. Look, J. R. Schullek, C. P. Homes, J. P. Chinn, E. M. Gordon, M. A. Gallop, Bioorg. Med. Chem. Lett., 1996, 6, 707-712.

[17] M. L. Barreca, J. Balzsarini, A. Chimirri, E. De Clercq, L. De Luca, H. D. Höltje, M. Höltje, A. M. Monforte, P. Monforte, C. Pannecouque, A. Rao, M. Zapalla, J. Med. Chem., 2002, 45, 5410-5413.

[18] A. Rao, J. Balzarini, A. Carbone, A. Chimirri, E. De Clercq, A. M. Monforte, P. Monforte, C. Pannecouque, M. Zapallà, Antiviral Res., 2004, 63, 79-84.

[19] R. K. Rawal, R. Tripathi, S. B. Katti, C. Pannecouque, E. De Clercq, Bioorg. Med. Chem., 2007, 15, 3134-3142.

[20] M. L. Barreca, A. Chimirri, L. De Luca, A. M. Monforte, P. Monforte, A. Rao, M. Zappala, J. Balzarini, E. De Clercq, C. Pannecouque, M. Witvrouw, Bioorg. Med. Chem. Lett., 2001, 11, 1793-1796.

[21] M. V. Diurno, O. Mazzoni, P. Eugenio, A. Calignano, F. Giordano, A. Bolognese, J. Med. Chem., 1992, 35, 2910-2912.

[22] R. Markovic, M. Stodanovic, P. Steel, E. Kleinpeter, M. Stojanovic, Heterocycles, 2005, 56, 2635-2647. 


\title{
Graphical Abstract
}

Chin. J. Catal., 2016, 37: 1997-2002 doi: 10.1016/S1872-2067(16)62536-6

Efficient approach to thiazolidinones via a one-pot three-component reaction involving 2-amino-1-phenylethanone hydrochloride, aldehyde and mercaptoacetic acid

Asha Vasantrao Chate, Akash Gitaram Tathe, Prajyot Jayadev Nagtilak, Sunil M. Sangle, Charansingh H. Gill* Dr. Babasaheb Ambedkar Marathwada University, India; Rajaram College, India

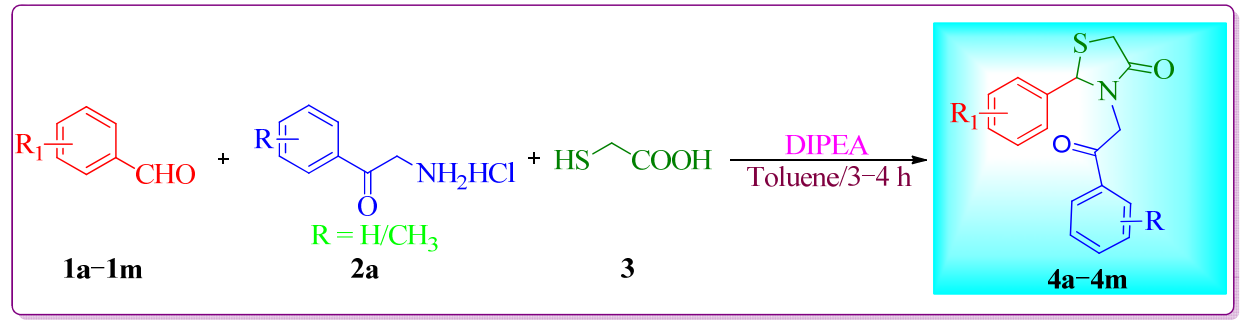

We report the design and synthesis of a novel series of the thiazolidinone derivatives $\mathbf{4 a}-\mathbf{4 m}$ under thermal conditions via the three-component reaction of 2-amino-1-phenylethanone hydrochloride with an aldehyde and mercaptoacetic acid in the presence of DIPEA using toluene as a solvent.

[23] R. B. Pawar, V. V. Mulwad, Chem. Heterocycl. Compd., 2004, 40, 219-226.

[24] N. Ocal, F. Aydogan, C. Yolacan, Z. Turgut, J. Heterocycl. Chem., 2003, 40, 721-724.

[25] S. K. Srivastava, S. L. Srivastava, S. D. Srivastava, J. Ind. Chem. Soc., 2002, 77, 104-105.

[26] R. C. Kumar, D. Kumar, J. Ind. Chem. Soc., 2002, 77, 492-493.

[27] R. K. Rawal, T. Srivastava, W. Haq, S. B. Katti, J. Chem. Res., 2004, 368-369.

[28] T. Srivastava, W. Haq, S. B. Katti, Tetrahedron, 2002, 58, 76197624.

[29] A. K. Yadav, M. Kumar, T. Yadav, R. Jain, Tetrahedron Lett., 2009, 50, 5031-5034.

[30] X. Y. Zhang, X. Y. Li, D. F. Li, G. R. Qu, J. J. Wang, P. M. Loiseau, X. S. Fan, Bioorg. Med. Chem. Lett., 2009, 19, 6280-6283.

[31] V. Kanagarajana, J. Thanusua, M. Gopalakrishnana, Green Chem.
Lett. Rev., 2009, 2, 161-167.

[32] C. P. Holmes, WO 9600148 Patent, 1996.

[33] V. Gududuru, V. Nguyen, J. T. Dalton, D. D. Miller, Synlett, 2004, 2357-2358.

[34] I. Ugi, B. Werner, A. Dömling, in: O. A. Attanasi, D. Spinelli, eds, Targets in Heterocycles Systems, Chemistry and Properties, Italian Society of Chemistry, Rome, 2000, Vol. 4, 1-23.

[35] I. Ugi, Pure Appl. Chem., 2001, 73, 187.

[36] A. Dömling, Chem. Rev., 2006, 106, 17-89.

[37] E. Ruijter, R. Scheffelaar, R. V. A. Orru, Angew. Chem. Int. Ed., 2011, $50,6234-6246$.

[38] F. C. Tenover, L. C. McDonald, Curr. Opin. Infect. Dis., 2005, 18 300-305.

[39] M. Delepine, Compt. Rend., 1895, 120, 501-502.

[40] L. M. Long, H. D. Trouliman, J. Am. Chem. Soc., 1949, 71, 24732475.

\section{一步法2-氨基-1-苯乙酮盐酸盐、醛和巯基乙酸三组分反应高效合成噻唑烷酮}

\author{
Asha Vasantrao Chate ${ }^{\mathrm{a}}$, Akash Gitaram Tathe ${ }^{\mathrm{a}}$, Prajyot Jayadev Nagtilak ${ }^{\mathrm{a}}$, \\ Sunil M. Sangle ${ }^{\mathrm{b}}$, Charansingh H. Gill ${ }^{\mathrm{a}, *}$ \\ a巴巴萨海布 - 安贝卡马拉特瓦达大学化学系, 奥兰加巴德 431004 , 马哈拉施特拉邦, 印度 \\ 拉贾拉姆学院, 戈尔哈布尔 416004 , 马哈拉施特拉邦, 印度
}

摘要: 采用一步法在二异丙基乙胺存在下由2-氨基-1-苯乙酮盐酸盐、芳香醛和颈基乙酸三组分反应高效合成了噻唑烷酮. 该反应显示出很好的化学选择性. 首先2-氨基-1-苯乙酮的 $\mathrm{N}$ 原子与芳香醛选择性反应生成席夫碱, 然后颈基乙酸的 $\mathrm{S}$ 原子 亲核进攻席夫碱的C原子, 最后 $\mathrm{N}$ 原子与羧酸基团环加成生成噻唑烷酮. 合成的化合物用光谱技术进行了表征. 关键词: 串联反应; 噻唑烷䣳; 杂环化合物; $N, N$-二异丙基乙胺; 成环作用

收稿日期: 2016-06-15. 接受日期: 2016-08-21. 出版日期: 2016-11-05.

*通讯联系人. 电话: +91-240-2403311; 传真: +91-240-2400491; 电子信箱: chgill16@gmail.com 本文的英文电子版由Elsevier出版社在ScienceDirect上出版(http://www.sciencedirect.com/science/journal/18722067). 